\title{
EFFECTS OF ACCOUNTING INFORMATION SYSTEM ON ORGANIZATION PERFORMANCE IN NIGERIA
}

\author{
${ }^{1}$ Olaofe-Obasesin, M. O, ${ }^{2}$ Akanni, W. A, ${ }^{3}$ Ekundayo O, 4Ajibola, O, 5Ajibola, F \\ ${ }^{1}$ Department of Accounting, Ekiti State University \\ 2Department of Mathematical Sciences, Anchor University Lagos \\ ${ }^{3}$ CT Department, Anchor University Lagos \\ ${ }^{4}$ Department of Banking and Finance, Yaba College of Technology \\ ${ }^{5}$ Department of Accounting, Anchor University Lagos
}

ABSTRACT - This paper examines accounting information system on performance of corporate organizations in Nigeria. The role of professionals in accounting, information technology and academics were explored. To attain the aim of the study, 30 questionnaires were administered and 25 retrieved which was analysed and the single factor ANOVA technique was used to test the hypothesis. Findings from the research depicted accounting information systems have a positive impact on corporate organizations performance in Nigeria because the observed $F$ of 251.43 obtained was greater than $F$ critical value of 2.74 . As recommended, corporate organizations should massively invest in accounting information system, adopt merit-based recruitment and ensure periodic training of accounting information systems personnel.

\author{
ARTICLE HISTORY \\ Revised: 30 April 2020 \\ Accepted: 20 July 2020
}

\section{KEYWORDS}

Accounting information system, financial management, information technology, organization, performance

\section{INTRODUCTION}

The importance of financial reporting to a business organization with consideration of its usage to the users of accounting information such as shareholders, management, government and its agencies, employees, financial analyst and researchers cannot be overemphasized (Obasesin and Olaoye, 2019). The basis of producing financial report in contemporary business lies on accounting information system which automates accounting information. The field of accounting information system is influenced by management information systems, economics, psychology, computer science \& organizational behavior (Ezenwoke et al 2019). Information Technology is essential in contemporary, competitive and dynamic business environment with consideration of its impact on qualitative information systems. It constitutes hardware, network, software, database and other essential tools which are useful for corporate org anizations accounting information systems (Shaukat and Zafarullah 2009; Kariuki, 2005; Olaoye, Olaofe-Obasesin and Akanni 2019).

There exists dearth of research papers of accounting information system on organizational performance in Nigeria. The need to provide solution to the dearth of papers in accounting information system on organizational performance in Nigeria necessitates this research by the authors. This paper, "accounting information systems and organizational performance in Nigeria" targets institutions in Lagos state. Section 2 reviews literature, section 3 deals with research methods, section 4 focuses on data analysis while section 5 concludes the paper with recommendations.

\section{REVIEW OF LITERATURE}

\section{A. Conceptual Framework}

A well-developed accounting information system enables efficiency and accuracy for a successful business operation. Accounting information system is a structure used by a business organization to collect process and report financial data for the use of professionals such as financial accountants, business analyst, consultants, chief financial officers, tax agencies, regulators and auditors. Accounting information system comprises people, data, internal controls, procedures, information technology infrastructures and software. People in accounting information system are the system users. They are the human elements who are professionals. The accounting information system data requires a database structure in the form of structured query language. Accounting information system internal controls aims at protecting structured data. The accounting information system procedures are methods in collecting, processing and reporting financial data. Information technology infrastructures are the hardware components on operating accounting information system while the software is the computer program for financial data storage and analysis. Quick-Books, Sage 50 Accounting, SAP, 
Microsoft Dynamics GP, Oracle People Soft, Sage Group MAS 200, Epicor Financial Management and others are the various software used by small, medium \& large business for financial data management (Fontinelle 2020).

\section{B. Theoretical Framework}

Technology Acceptance Model (TAM): The model was developed by Davis which is widely believed as one of the influential models in information technology. In this model, usefulness and ease of use were prioritized. Perceived usefulness is a degree at which an individual is of the belief the usage of system would enhance job performance. Perceived ease of use targets intends users' information technology usage without much effort. The model highlights the effective use of computers efficiently (Davis 1989; Rogers 1983; Hashim et al 2012; Olaoye, Olaofe-Obasesin and Akanni 2019).

Information System Success Model: The component of information system success includes information quality, system quality, organizational impact, user satisfaction, individual impact and use. This is subject to management information system quality, management support, managerial decision-making quality, perceived usefulness, information quality and the satisfaction of decision makers. The adoption of this model is based on the effects of system quality on information quality/managerial decision making (Petter, De Lone and Mc Lean 2003).

\section{Empirical Review}

Awosejo et al (2013) opined information and communication technology has improved professional service quality in accounting organization. The study observed technology acceptance model of behaviors, intent, attitude usage, perceived usefulness and ease of use enabled the attainment of accounting information systems usage. The technology acceptance model factors depicted a significant effect on accounting information systems from the South-African content. The research recommended formal education and training of users on AIS for adequate improvement. Olaoye, OlaofeObasesin and Akanni (2019) examined the impact of information technology on corporate organizations performance in Nigeria. The empirical research findings revealed information technology has a significant impact on corporate organizations performance in Nigeria with recommendations on prioritizing personnel training and massive investment in information technology for efficiency in operations. Ezenwoke et al (2019) was of the view accounting information system has the influential role of automating accounting information. The research prioritized analyzing work volume on accounting information system and noted scarce literature of accounting information system on the Scopus publication domain. The paper acknowledged the adoption of accounting information system in most developed economies and recommended high investments in information and communication technology and also on education in the developing economies. Hashim et al (2012) conducted a research on the impact of management information system on the overall performance and efficiency of the workforce of the Peshawar Accountant General office with emphasis on System Application Product (SAP). The research recommends training program on SAP, embargo on manual work, merit base employment, entry access of employee to data, provision of modern-day technological equipment and the need of Peshawar government to adequately remunerate employees.

Kearms (2014) affirmed accounting information system is an integral part of accounting information programs. Response from questionnaires on the importance of accounting information systems in the accounting curricular supported the influence of accounting information system to practitioners. He observed lack of research in specific accounting knowledge as acknowledged by the International Federation of Accountants (IFAC), American Accounting Association (AAA), Institute of Management Accountants, Institute of Internal Auditors (IIA) and the American Institute of Certified Public Accountants (AICPA). Educators suggested IT leverages personnel competencies, functional competencies and broad business perspective competencies. The researcher observed individual skill sets from Certified Public Accountants perspective in past research has been ignored and little attention was noted in accounting information system comparative skills with recommendations to future researchers to increase findings based on job function time in profession, size of firm, management status and time in industry. Ahmad (2013) paper on the impact of using accounting information system on the quality of financial statements to income tax department in Jordan revealed a positive and high presence with recommendations on training personnel and development of various information technology devices used in the department. Srinivas (2011) conceptualized transactional processing systems, management information systems \& expert systems as the three types of information systems, with decisions support system \& executive information systems as management information system subset. The research noted the challenges of management information system include dynamism, decisions dynamism, institutionalization, finance, science-oriented field as against art-oriented \& lack of organizational structure but recommended monitoring, information gateway channel \& well-defined structure for ideal decision-making system. The research executed by Olaoye, Akinleye, Olaoye and Obasesin (2019) on the significance of accounting system on performance of non-profit organization in Nigeria asserted a good financial report comprises relevance, verifiability, timeliness, under stability and completeness. Their findings depict accounting system has a significant impact on the performance of non-profit organizations with recommendations on proper recruitment procedure, annual audit of financial statements and avenue for good accounting \& internal control systems by the management. 


\section{Gap in Literature}

Several research works have been executed on accounting information system. Awosejo et al (2013) examined the effect of accounting information systems in accounting. Olaoye, Olaofe-Obasesin and Akanni (2019) carried out research on the impact of information technology on corporate organization performance in Nigeria. Ezenwoke et al (2019) worked on the bibliometric study of accounting systems research from 1975 to 2017. Hashim et al (2019) conducted a research on impact of management information system on the overall performance and efficiency of the workforce of the Peshawar Accountant General Office. Kearms (2014) investigated the importance of accounting information systems in the accounting curricula. Ahmad (2013) researched on the impact of using accounting information systems on the quality of financial statements in Jordan. Srinivas (2011) carried out study on management information systems and business decision making while Olaoye, Akinleye, Olaoye and Olaoye (2019) executed a research on the significance of accounting system on performance of non-profit organizations in Nigeria. This research "effects of accounting information systems on organization performance in Nigeria" will fill the gap since none have fully discussed it.

\section{METHODOLOGY}

This research seeks to determine accounting information systems on organizational performance in Nigeria. Questionnaire was the primary source of data with the use of Likert scale of Strongly Agree (SA), Agree (A), Disagree (D) and Strongly Disagree (SD). Professionals in accounting, academics and information technology constitute the population of study in Lagos State. The results of the research will be presented using percentages, averages and standard deviation. Thirty respondents were administered through questionnaires and twenty-five was returned representing $90 \%$. The one-way ANOVA technique was used for analysis with test of significance @ 5\% level using n-1 degree of freedom.

\section{DATA ANALYSIS}

\section{A. Presentation of Data}

Table 1: Distribution of responses on accounting information system and organization performance

\begin{tabular}{|lcccc|}
\hline AIS \& Organization Performance & SA & A & D & SD \\
\hline & $\%$ & $\%$ & $\%$ & $\%$ \\
\hline AIS aids work efficiency & 40 & 36.7 & 10 & 13.3 \\
\hline AIS equipment are up to date & 23.3 & 30 & 26.7 & 20 \\
\hline Employees in AIS units have required qualification & 33.3 & 26.7 & 23.3 & 16.7 \\
\hline AIS training adds to work performance & 46.7 & 33.3 & 13.3 & 6.7 \\
\hline AIS is suitable for decision making & 40 & 43.4 & 10 & 6.7 \\
\hline Source: Survey & & & & \\
\hline
\end{tabular}

Control Activities

Of the 25 respondents, $76.7 \%$ agreed accounting information system facilitates work efficiency while $23.3 \%$ disagreed. $53.3 \%$ agreed accounting information system equipment are up to date as $46.7 \%$ disagreed. $60 \%$ of the respondents agreed that employees in accounting information system sections possessed the required qualification while $40 \%$ disagreed. On whether accounting information system adds value to work performance, $80 \%$ agreed while $20 \%$ disagreed. Lastly, $83.3 \%$ agreed accounting information system is suitable for decision making while $16.7 \%$ disagreed.

\section{B. Analysis of Data}

Table 2: Analysis of responses on accounting information systems and organization performance.

\begin{tabular}{|lrrrrc|}
\hline AIS \& Organizational Performance & Mean & Std Dev. & Var. & Skew. & Kur. \\
\hline AIS aids work efficiency & 1.97 & 1.033 & 1.668 & .874 & -2.77 \\
\hline AIS equipment are up to date & 2.43 & 1.073 & 1.151 & .095 & -1.196 \\
\hline Employees in AIS units have qualification & 2.23 & 1.104 & 1.220 & .325 & -1.219 \\
\hline AIS training adds to work performance & 1.80 & .925 & .825 & .987 & -1.95 \\
\hline AIS is suitable for decision making & 1.83 & .874 & .764 & 1.017 & .687 \\
\hline Source: Authors Computation & & & & & \\
\hline
\end{tabular}




\section{Test of Hypothesis}

Table 3: Accounting information systems and organization performance

ANOVA: Single Factor

\begin{tabular}{|lcccccr|}
\hline Source of Variation & Sum of Squares & Deg. of Freed & Mean Squares & F & Significance & F,Crit \\
\hline Between Groups & 99.541 & 3 & 33.18 & 251.43 & .001 & 2.74 \\
\hline Within Groups & 16.16 & 26 & 0.622 & & & \\
\hline Total & 115.701 & 29 & & & & \\
\hline
\end{tabular}

Hypothesis

H0: Accounting information system has no significant impact on performance of organizations in Nigeria

H1: Accounting information system has significant impact on performance of organizations in Nigeria

At $5 \%$ level of significance, with degree of freedom at 3 and 26, observed is 251.43 which is greater than 2.74 . H0 is hereby rejected, thus accounting information system has significant impact on performance of organizations in Nigeria.

\section{DISCUSSION OF RESULTS}

As computed from Table 2, the mean comparability revealed accounting information systems equipment are up to date at 2.43 while 1.104 of employees in accounting information system units possessed the required qualification based on standard deviation. The sharpness of the frequency distribution from the table, that is Kurtosis depicted negative except for the computation on suitability of accounting information system for decision making which revealed 0.687.

\section{CONCLUSION AND RECOMMENDATIONS}

The conclusion of this research is that accounting information systems will significantly improve the performance of corporate organizations in Nigeria. As confirmed through the statistical analysis result, observed F of 251.43 was greater than the 2.74 F critical value using the Statistical Package for the Social Sciences.

The following recommendations are essentials:

a. Corporate organizations should imbibe merit-based recruitment process of newly recruit who possessed required skills, abilities and knowledge.

b. Assive investment on accounting information systems equipment for effective and efficient operations will add short-, medium- and long-term value to the organization.

c. He needs for awareness orientation on accounting information system equipment usage and regular training of professionals such as accountants, chief finance officers, government agencies employees and auditors.

\section{ACKNOWLEDGEMENT}

The authors appreciate Ekiti State University and Anchor University Lagos on mentorship and provision of available infrastructure in making this research a success. Also, to Miss Onyeka Odega of Yaba College of Technology who is on internship at Internal Audit Department of Anchor University for the clerical support.

\section{REFERENCES}

[1] Ahmad, A.A (2013) The Impact of Using Accounting Information Systems on the Quality of Financial Statements in Jordan. European Scientific Journal, 1(1), $41-48$

[2] Awosejo, O J, Kekwaletswe, R. M. Pretorius, P \& Zuva T (2013). The Effect of Accounting Information Systems in Accounting. International Journal of Advanced Computer Research, 3 (3), 142 - 151

[3] Davis, F. D (1989) Perceived usefulness, perceived ease of use, and user acceptance of information technology, MIS Quarterly 13 (3), $319-340$

[4] De Lone, W. H \& McLean, E. R (2003). The De Lone and McLean Model of Information Systems Success: A Ten-Year Update. Journal of Management Information Systems, 19 (4), 9-30. 
[5] Ezenwoke, O. Ezenwoke, A. Eluyela, A and Olusanmi.O (2019). A bibliometric study of accounting information systems research from 1975-2017. Asian J. Sci. Res., 12, 2019, 167-178

[6] Fontinelle, A (2020). Introduction to Accounting Information Systems. www.investopedia.com/articles/professionaleducation/11/accounting-information-systems. 2020.

[7] Hashim, M. Yousaf, A \& Khan, S (2012). The impact of Management Information System on the Overall Performance and Efficiency of the Workforce of the Accountant General (Peshawar): A Research Base Study. International Journal of Academic Research in Accounting, Finance and Management Sciences, 2 (2), 167 -182

[8] Kariuki, A. M (2014). Impact of Information Technology on Organizational Performance: Case of population services in Kenya. A Master of Business Administration Thesis submitted to University of Nairobi.

[9] Kearns G. S (2014). The Importance of Accounting Information Systems in the Accounting Curricula: A CPA Perspective. AIS Educator Journal, 9 (1), 24 - 40.

[10] Obasesin, M. 0 \& Olaoye, F. O (2019). The Impact of Ethics on Financial Report of Corporate Organizations in Nigeria. Proceedings of Conference on Advanced Research in Management, Economics and Accounting, Barcelona, 5th September, 2019. ISBN 978-609-485-003-5

[11] Olaoye, F. O, Olaofe-Obasesin, M. O \& Akanni, W (2019). The Impact of Information Technology on Corporate Organizations Performance in Nigeria. International Journal of Engineering Applied Sciences and Technology, 4 (8), $84-88$.

[12] Olaoye, C. O, Akinleye, G. T, Olaoye F. O \& Obasesin, M. O (2019). The Significance of Accounting System on Performance of Nonprofit Organizations in Nigeria. Advanced Journal of Current Research, 6 (10), $72-78$.

[13] Petter, S \& Fruhlingb, A (2011). Evaluating the success of an emergency response medical information system. International journal of medical informatics, 80 (7), 480-489.

[14] Rogers, E. M (1983). Diffusion of Innovations. New York, Free Press.

[15] Shaukat, M \& Zafarullah, M (2009). Impact of Information Technology on Organizational Performance: An analysis of Quantitative Performance Indicators of Pakistan Banking and Manufacturing Companies. European Journal of Economics, Finance and Administrative Sciences, Issue 16.

[16] Srinivas, N (2011). Management information systems and business decision making: review, analysis, and recommendations. Journal of Management and Marketing Research, $1-8$. 